\title{
PENGARUH PROFITABILITAS DAN PERTUMBUHAN ASET TERHADAP KEBIJAKAN DIVIDEN DAN NILAI PERUSAHAAN
}

\author{
Anak Agung Gde Agung Nanda Perwira ${ }^{1}$ \\ I Gusti Bagus Wiksuana ${ }^{2}$
}

\author{
${ }^{1,2}$ Fakultas Ekonomi dan Bisnis Universitas Udayana, Bali, Indonesia \\ email: nandaperwira25@gmail.com
}

\begin{abstract}
ABSTRAK
Perusahaan Manufaktur yang terdaftar di BEI peiode 2013-2016 cenderung mengalami fluktuasi nilai perusahaan. Diduga Return On Investment (ROE), Asset Growth dan Dividend Payout Ratio (DPR) yang menjadi salah satu faktor penyebabnya. Penelitian ini dilakukan di Bursa Efek Indonesia (BEI). Populasi yang digunakan yaitu perusahaan manufaktur. Metode penentuan sampel yang digunakan adalah purposive sampling. Dimana dalam penelitian ini menggunakan kriteria perusahaan yang membagikan dividennya dari tahun 2013 hingga 2016. Analisis data yang digunakan yaitu analisis jalur ( path analysis). Berdasarkan hasil analisis penelitian ini ditemukan bahwa ROE berpengaruh positif dan signifikan terhadap DPR, Asset Growth berpengaruh positif dan signifikan terhadap DPR, ROE berpengaruh positif dan signifkan terhadap PBV, Asset Growth berpengaruh positif dan signifikan terhadap PBV dan DPR berpengaruh positif signifikan terhadap PBV. Perusahaan manufaktur diharapkan lebih teliti dalam membuat keputusan tentang kebijakan dividen karena dapat mempengaruhi nilai perusahaan.
\end{abstract}

Kata kunci: nilai perusahaan, kebijakan dividen, ROE, dan asset growth.

\begin{abstract}
Manufacturing Companies listed on the BEI period 2013-2016 tend to experience fluctuations in corporate value. Suspected Return On Investment (ROE), Asset Growth and Dividend Payout Ratio (DPR) which became one of the factors causing it.. This research is conducted at Indonesia Stock Exchange (BEI). The population used is manufacturing companies. Sampling method used is purposive sampling. Where in this study using criteria of companies that distribute dividends from 2013 to 2016. Data analysis used is path analysis (path analysis). Based on the results of this research analysis found that ROE has a positive and significant effect on House of Representatives, Asset Growth has a positive and significant influence on House of Representatives, ROE has positive and significant influence on PBV and Asset Growth have significant positive effect on PBV. Manufacturing companies are expected to be more rigorous in making decisions about dividend policy because it can affect the value of the company.
\end{abstract}

Keywords: corporate value, dividend policy, ROE, and asset growth. 


\section{PENDAHULUAN}

Berdirinya suatu perusahaan memiliki tujuan yang jelas, baik jangka pendek dan jangka panjang. Memperoleh laba yang maksimal adalah tujuan utama dari suatu perusahaan sedangkan memberikan kemakmuran bagi pemilik perusahaan atau pemegang saham dan memaksimalkan nilai perusahaan adalah tujuan jangka panjangnya (Ista'adah, 2015). Nilai perusahaan merupakan seberapa besar harga yang bersedia dibayar oleh calon pembeli apabila perusahaan terjual. Optimalisasi nilai perusahaan dapat dicapai dengan pelaksanaan fungsi manajemen keuangan yaitu mengambil keputusan-keputusan penting seperti keputusan pendanaan, keputusan investasi dan kebijakan dividen. Satu keputusan keuangan akan berdampak pada keputusan keuangan lainnya. Suatu kombinasi yang optimal akan mampu memaksimalkan nilai perusahaan yang selanjutnya akan meningkatkan kemakmuran serta kekayaan pemegang saham. (Afzal dan Rohman, 2012). Perusahaan yang tidak go public atau tidak menjual sahamnya di pasar modal apabila menjual perusahaan, nilai perusahaan dapat diukur dengan harga jualnya karena mampu mencerminkan nilai aset perusahaan, tingkat resiko usaha, prospek perusahaan serta manajemen dan lingkungan perusahaan.

Berbeda dengan perusahaan tidak go public, perusahan go public menjual sahamnya di pasar modal dan nilai perusahaan dapat dilihat dari harga saham yang diperjual-belikan di pasar modal (Sartono, 2010:9). Indonesia memiliki pasar modal yaitu Bursa Efek Indonesia yang mempertemukan investor dan pelaku usaha sebagai alternatif investor untuk berinvestasi. Terdapat instrumen 
penting yang ditawarkan dalam pasar modal yaitu saham preferens, obligasi dan saham biasa (Sartono, 2010:23).

Nilai perusahaan merupakan harga yang bersedia dibayarkan oleh calon pembeli apabila perusahaan akan dijual. Tingginya nilai perusahaan akan mempengaruhi tingkat kemakmuran pemegang saham. Memiliki perusahaan dengan tingkat nilai perusahaan yang tinggi menjadi keinginan calon pembeli, karena nilai perusahaan yang tinggi akan cenderung memakmurkan pemegang saham. Kekayaan pemegang saham dan perusahaan ditunjukan oleh harga saham yang merupakan cerminan dari keputusan investasi pendanaan (financing) dan manajemen aset. Adanya peluang investasi dapat memberikan sinyal positif tentang pertumbuhan perusahaan di masa yang akan datang, sehingga dapat meningkatkan nilai perusahaan ( Prastuti dan Sudiartha, 2016).

Firm value atau enterprise value adalah salah satu pedoman atau konsep yang digunakan oleh investor, karena merupakan indicator bagi pasar dalam menilai perusahaan secara keseluruhan ( Salvatore,2011:9). Price to book value (PBV) adalah rasio harga saham terhadap nilai buku perusahaan yang menunjukan tingkat kemampuan perusahaan menciptakan nilai relatif terhadap jumlah modal yang diinvestasikan. PBV yang tinggi mencerminkan harga saham yang tinggi yang dibandingkan dengan nilai buku perlembar saham. Semakin tinggi harga saham, semakin berhasil pula perusahaan menciptakan nilai bagi pemegang saham. Keberhasilan perusahaan menciptakan nilai tersebut tentunya memberikan harapan bagi pemegang saham berupa keuntungan yang lebih besar pula. Secara sederhana price to book value (PBV) merupakan rasio pasar (market ratio) yang 
digunakan untuk mengukur kinerja harga saham terhadap nilai bukunya. (Salvatore, 2011:12)

Harga saham yang tinggi menandakan pemegang saham menjadi lebih kaya dan lebih makmur ( Hermuningsih dan Dewi, 2009). Nilai perusahaan dapat diukur dari return saham perusahaan yang berupa capital gain dan dividen karena ekspetasi dari investor dalam investasinya adalah mendapatkan return (tingkat pengembalian) sebesar-besarnya dalam resiko tertentu. Return adalah indikator untuk meningkatkan kekayaan dari investor (Wahyuati, 2015). Beberapa variabel yang mempengaruhi nilai perusahaan adalah profitabilitas, pertumbuhan aset, serta kebijakan dividen yang termasuk variabel ekonomi mikro atau variabel yang dapat dikendalikan oleh perusahaan (Goblin dkk., 2013). Tinggi rendahnya nilai perusahaan dapat dipengaruhi oleh beberapa faktor yaitu profitabilitas, pertumbuhan aset dan kebijakan dividen

Profitabilitas menunjukan kemampuan perusahaan memperoleh laba atau ukuran efektivitas pengelolaan manajemen perusahaan (Wiagustini, 2010:76). Terdapat tiga rasio yang sering digunakan yaitu profit margin, return on total asset (ROA), dan return on equity (ROE). Profit margin menghitung sejauh mana kemampuan perusahaan menghasilkan laba bersih pada tingkat penjualan tertentu. Rasio ini diinterpretasikan juga sebagai kemampuan perusahaan menekan biayabiaya (ukuran efisiensi) diperusahaan pada periode tertentu. Return on asset (ROA) mengukur kemampuan perusahaan menghasilkan laba bersih berdasarkan tingkat asset tertentu. Return on equity (ROE) menggambarkan kemampuan perusahaan menghasilkan laba berdasarkan modal saham tertentu. Rasio ini 
merupakan ukuran profitabilitas dari sudut pandang pemegang saham (Islami dan Djawoto, 2014).

Profitabilitas sangat penting dalam mempertahankan kelangsungan perusahaan untuk jangka panjang, hal ini disebabkan karena profitabilitas menunjukan prospek perusahaan di masa yang akan datang. Dalam pengelolaan memperoleh laba yang maksimal, seorang manajer harus bekerja dengan baik sehingga perusahaan mendapat laba yang besar dengan mengeluarkan biaya yang kecil. Semakin besar laba yang diperoleh perusahaan akan mampu meningkatkan nilai perusahaan (Wijaya dan Sedana, 2015). Hal ini menyimpulkan bahwa profitabilitas memiliki hubungan positif secara langsung terhadap nilai perusahaan. Serupa dengan penelitian Chen dan Chen (2011) dan Winarto (2015) yang menyatakan bahwa profitabilitas memiliki hubungan positif terhadap nilai perusahaan. Berbeda dengan Juhandi dkk. (2013) yang menyatakan bahwa profitabilitas memiliki negatif dan signifikan terhadap nilai perusahaan.

Kemampuan perusahaan dalam menghasilkan laba akan mempengaruhi tingkat pembayaran dividen. Semakin banyak laba yang dihasilkan oleh perusahaan maka semakin tinggi juga kemungkinan perusahaan akan mampu memenuhi kewajibannya dalam membayarkan dividen untuk pemegang saham (Wiagustini, 2010:257). Dengan tingginya pembayaran dividen kepada pemegang saham akan meningkatkan nilai perusahaan. Menurut Aqel (2016) dan Yegon et al. (2014) terdapat pengaruh positif profitabilitas terhadap nilai perusahaan melalui kebijakan dividen. 
Pihak internal maupun eksternal perusahaan akan menginginkan pertumbuhan aset yang terus meningkat. Signaling theory menyatakan bahwa profitabilitas dan pengeluaran investasi berdampak positif bagi perusahaan yaitu memberikan kesempatan berinvestasi bagi investor dalam perusahaan. Pertumbuhan aset yang meningkat akan memiliki prospek yang menguntungkan dalam investasi karena kemungkinan return yang akan diperoleh juga tinggi sehingga menjadi sinyal positif bagi investor yang menyebabkan meningkatnya harga saham (Ratnawati, 2007). Pertumbuhan aset mempunyai efek yang kuat terhadap nilai perusahaan terutama dalam perusahaan kecil dan menengah, karena dengan melihat investasi perusahaan atau kegiatan pembiayaan yang dilakukan, maka investor dapat memprediksi tingkat return yang akan didapatkan (Cooper $e t$ al. 2008). Penelitian terdahulu oleh Li et al. (2012) menemukan bahwa pertumbuhan aset memiliki pengaruh positif secara langsung terhadap nilai perusahaan, berbeda dengan penelitian yang dilakukan oleh Jenni et al. (2011) justru menemukan bahwa pertumbuhan aset tidak berpengaruh terhadap return saham.

Dividen adalah pembagian laba yang diperoleh perusahaan kepada para pemegang saham yang sebanding dengan jumlah saham yang dimiliki. Dividen dapat berupa uang tunai maupun saham. Stice et al. (2005) dan Deitiana (2009) mengartikan dividen sebagai pembagian laba kepada para pemegang saham perusahaan sebanding dengan jumlah saham yang dipegang oleh masing-masing pemilik. Dividen yang dibagikan kepada pemegang saham dapat dinyatakan 
sebagai persentase atas nilai saham atau sejumlah uang tiap lembar saham yang dimiliki.

Besarnya pembayaran dividen salah satunya disebabkan oleh pertumbuhan aset, yang nantinya akan mempengaruhi nilai perusahaan. Rismawati dan Dana (2014) menyatakan bahwa terdapat hubungan positif secara tidak pertumbuhan aset terhadap nilai perusahaan melalui kebijakan dividen.

Tabel 1.

Nilai Perusahaan Manufaktur di Bursa Efek Indonesia yang Membayar Dividen Berturut - turut Tahun 2013 - 2016.

\begin{tabular}{|c|c|c|c|c|c|c|}
\hline \multirow{2}{*}{ No. } & \multirow{2}{*}{ Nama Perusahaan } & \multirow{2}{*}{ Kode } & \multicolumn{4}{|c|}{ Price to Book Value (PBV) (\%) } \\
\hline & & & 2013 & 2014 & 2015 & 2016 \\
\hline 1. & Astra International Tbk. & ASII & 259.25 & 249.82 & 191.95 & 254.17 \\
\hline 2. & Astra Otoparts Tbk. & AUTO & 184.04 & 199.70 & 76.03 & 96.06 \\
\hline 3. & Sepatu Bata Tbk. & BATA & 347.23 & 334.76 & 213.82 & 180.77 \\
\hline 4. & Charoen Pokphand Indonesia Tbk. & CPIN & 556.16 & 556.41 & 339.41 & 346.95 \\
\hline 5. & Ekadharma International Tbk. & EKAD & 114.65 & 131.72 & 95.74 & 78.60 \\
\hline 6. & Gudang Garam Tbk. & GGRM & 274.72 & 351.48 & 278.43 & 327.13 \\
\hline 7. & HM Sampoerna Tbk. & HMSP & 1932.17 & 2229.15 & 1366.05 & 1293.35 \\
\hline 8. & $\begin{array}{l}\text { Indofood CBP Sukses Makmur } \\
\text { Tbk. }\end{array}$ & ICBP & 448.34 & 507.88 & 479.48 & 561.18 \\
\hline 9. & $\begin{array}{l}\text { Indomobil Sukses Internasional } \\
\text { Tbk. }\end{array}$ & IMAS & 203.46 & 164.43 & 97.65 & 59.12 \\
\hline 10. & Indofood Sukses Makmur Tbk. & INDF & 151.02 & 143.75 & 105.37 & 154.96 \\
\hline 11. & Indah Kiat Pulp \& Paper Tbk. & INKP & 27.21 & 19.09 & 13.59 & 14.79 \\
\hline 12. & Indocement Tunggal Prakarsa Tbk. & INTP & 320.42 & 371.32 & 334.35 & 188.03 \\
\hline 13. & Kalbe Farma Tbk. & KLBF & 746.76 & 873.76 & 565.67 & 601.14 \\
\hline 14. & Semen Indonesia (Persero) Tbk. & SMGR & 384.93 & 384.33 & 246.42 & 178.00 \\
\hline 15. & Selamat Sempurna Tbk. & SMSM & 493.33 & 596.28 & 475.81 & 90.56 \\
\hline 16. & Mandom Indonesia Tbk. & TCID & 202.26 & 274.54 & 193.46 & 143.86 \\
\hline 17. & Pabrik Kertas Tjiwi Kimia Tbk. & TKIM & 24.55 & 19.61 & 9.44 & 16.42 \\
\hline 18. & Surya Toto Indonesia Tbk. & тото & 368.30 & 159.93 & 480.87 & 32.62 \\
\hline 19. & Trisula International Tbk. & TRIS & 142.06 & 120.06 & 95.26 & 98.37 \\
\hline 20. & Trias Sentosa Tbk. & TRST & 41.06 & 60.58 & 44.48 & 45.42 \\
\hline
\end{tabular}

Sumber : Data sekunder diolah ,2017 
Pertumbuhan sektor industri manufaktur mempunyai posisi yang dominan dalam perkembangan perekonomian Indonesia. Hal ini ditunjukan dengan terdapatnya 144 perusahaan manufaktur dari 539 jumlah perusahaan yang terdaftar pada Bursa Efek Indonesia tahun 2013 sampai dengan tahun 2016 (www.idx.com). Kondisi perekonomian sangat mempengaruhi perolehan laba perusahaan manufaktur karena berhubungan langsung dengan daya beli masyarakat sehari-hari. Sektor industri manufaktur juga memiliki target dividend payout ratio (DPR) paling tinggi dibandingkan sektor lainnya. Semakin tinggi investasi maka nilai perusahaan akan tercemin dari investasi tersebut. Namun pada tahun 2013-2016 terdapat fluktuasi pembagian dividen yang dilakukan oleh perusahaan manufaktur yang terdaftar di bursa efek Indonesia yang dapat dilihat dari Tabel 1.

Tabel 1 menunjukkan nilai perusahaan yang diproksikan dengan PBV pada perusahaan manufaktur tahun 2013 - 2016 mengalami fluktuasi. Nilai perusahaan tertinggi selama periode 2013 - 2016 dimiliki oleh HM Sampoerna Tbk. Nilai perusahaan terendah pada tahun 2014 dan 2016 dimiliki oleh Indah Kiat Pulp \& Paper Tbk. sedangkan nilai perusahaan terendah pada tahun 2013 dan 2015 Pabrik Kertas Tjiwi Kimia Tbk. Melihat nilai perusahaan yang tidak stabil, investor akan menganggap kredibilitas perusahaan menurun.

Signaling theory menyatakan bahwa profitabilitas dan pengeluaran investasi memberikan sinyal positif mengenai pertumbuhan perusahaan di masa yang akan datang. Informasi mengenai jenis pengeluaran investasi memiliki pengaruh besar terhadap nilai perusahaan, karena dapat memberikan sinyal tentang pertumbuhan 
pendapatan yang diharapkan di masa depan, yang selanjutnya akan meningkatkan harga saham sebagai indikator nilai peusahaan. Keuntungan yang diperoleh perusahaan dan kinerja perusahaan ditentukan salah satunya dengan keputusan investasi yang dilakukan. Keputusan ini sangat penting karena jika salah dalam mengambil keputusan, maka akan mengganggu kelangsungan hidup peusahaan. Manajer dalam hal ini harus memiliki kinerja yang baik sehingga dapat menjaga perkembangan investasi dengan demikian dapat mencapai tujuan perusahaan melalui kesejahteraan pemegang saham dan peningkatan nilai perusahaan ( Noerirawan dan Abdul, 2012).

Menurut Kasmir (2011:196), yang menyatakan bahwa rasio profitabilitas merupakan rasio untuk menilai kemampuan perusahaan dalam mencari keuntungan. Rasio keuntungan atau profitability ratios adalah rasio yang digunakan untuk mengukur efisiensi penggunaan aktiva perusahaan atau merupakan kemampuan suatu perusahaan untuk menghasilkan laba selama periode tertentu (biasanya semesteran, triwulanan dan lain-lain) untuk melihat kemampuan perusahaan dalam beroperasi secara efisien. Dengan demikian dapat ditarik kesimpulan bahwa rasio profitabilitas adalah rasio untuk mengukur tingkat efektifitas pengelolaan (manajemen) perusahaan yang ditunjukkan oleh jumlah keuntungan yang dihasilkan dari penjualan dan investasi.

Signaling theory menyatakan bahwa profitabilitas dan pengeluaran investasi memberikan sinyal positif mengenai pertumbuhan perusahaan di masa yang akan datang. Informasi mengenai jenis pengeluaran investasi memiliki pengaruh besar terhadap nilai perusahaan, karena dapat memberikan sinyal tentang pertumbuhan 
pendapatan yang diharapkan di masa depan, yang selanjutnya akan meningkatkan harga saham sebagai indikator nilai peusahaan. Keuntungan yang diperoleh perusahaan dan kinerja perusahaan ditentukan salah satunya dengan keputusan investasi yang dilakukan. Keputusan ini sangat penting karena jika salah dalam mengambil keputusan, maka akan mengganggu kelangsungan hidup peusahaan. Manajer dalam hal ini harus memiliki kinerja yang baik sehingga dapat menjaga perkembangan investasi dengan demikian dapat mencapai tujuan perusahaan melalui kesejahteraan pemegang saham dan peningkatan nilai perusahaan ( Noerirawan dan Abdul, 2012).

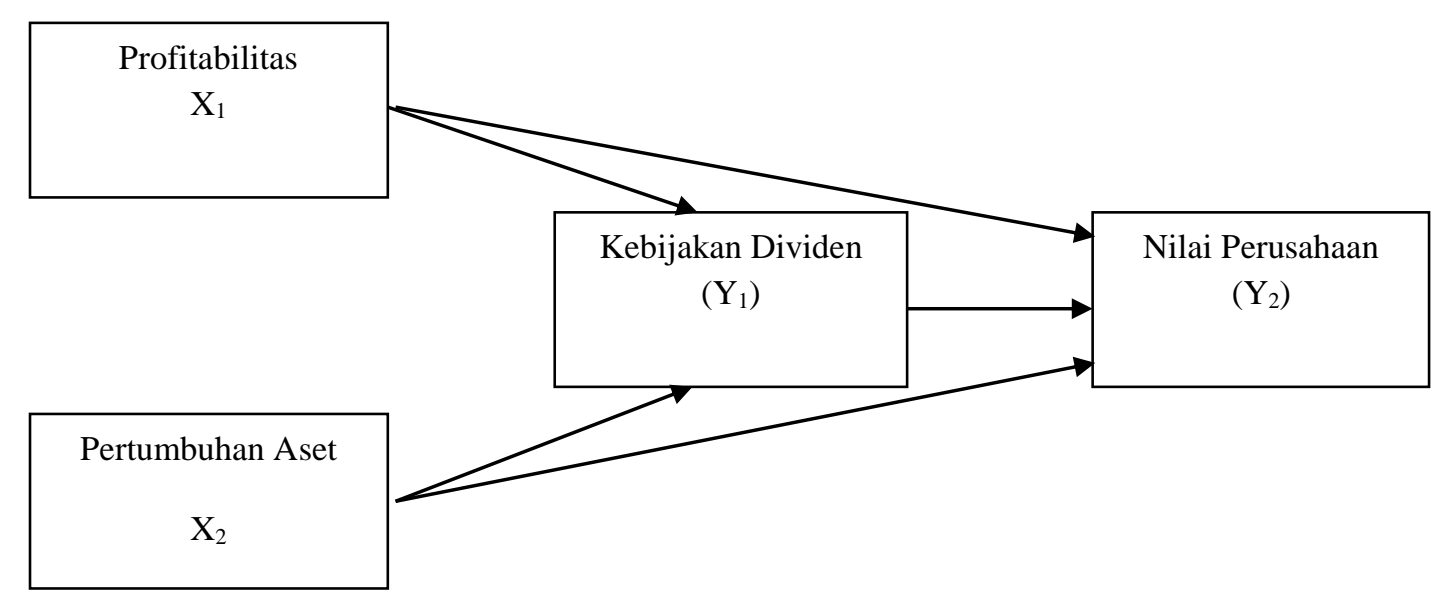

\section{Gambar 1. Kerangka Konseptual}

Silaban (2016) menyatakan bahwa pihak manajemen akan membayarkan dividen untuk memberikan sinyal mengenai keberhasilan perusahaan dalam membukukan profit. Sinyal tersebut menyimpulkan bahwa kemampuan perusahaan untuk membayar dividen merupakan fungsi dari keuntungan perusahaan. Perusahaan yang memperoleh keuntungan cenderung akan membayar dividen. Semakin besar keuntungan yang diperoleh maka akan semakin besar pula kemampuan perusahaan untuk membayar dividen. Hal tersebut sejalan dengan 
penelitian yang dilakukan oleh Wijaya dan Sedana (2015) mengemukakan hal yang sama, yaitu profitabilitas berpengaruh positif dan signifikan terhadap kebijakan dividen. Dapat ditarik hipotesis bahwa:

$\mathrm{H}_{1}$ : Profitabilitas berpengaruh positif dan signifikan terhadap kebijakan dividen Setiawan dan Phua (2013) menyatakan bahwa perusahaan yang mempunyai pertumbuhan asset yang baik dapat membayar kewajiban kepada pemegang saham dengan lancar. Hal ini membuktikan bahwa pertumbuhan aset mempunyai pengaruh positif terhadap kebijakan dividen. Berdasarkan hasil penelitian Corina (2012), Masdupi (2012) dan Ismail (2016) menyatakan hal yang sama yaitu perusahaan yang mampu membayarkan dividennya adalah perusahaan dengan pertumbuhan aset yang baik karena perusahan berpeluang mendapatkan return yang tinggi. Berdasarkan beberapa uraian diatas maka disimpulkan bahwa :

$\mathrm{H}_{2}$ : Pertumbuhan aset berpengaruh positif dan signifikan terhadap kebijakan dividen.

Rizqia dkk. (2013) menyatakan bahwa dalam perusahaan yang dapat menjaga kestabilan dan meningkatkan laba dapat dilihat sebagai sinyal positif oleh investor berkaitan dengan kinerja perusahaan. Hal tersebut terjadi disebabkan perusahaan yang mengalami peningkatan laba mencerminkan bahwa perusahaan mempunyai kinerja yang baik, sehingga menimbulkan sentimen positif dari investor dan dapat membuat harga saham perusahaan mengalami peningkatan.

Meningkatnya harga saham di pasar berarti meningkat pula nilai perusahaan di mata investor. Hasil penelitian yang dilakukan oleh Rizqia dkk. (2013) sejalan 
dengan penelitian Wijaya dan Sedana (2015) yang menunjukkan bahwa profitabilitas berpengaruh positif terhadap nilai perusahaan. Berdasarkan beberapa uraian diatas maka disimpulkan bahwa :

$\mathrm{H}_{3}$ : Profitabilitas berpengaruh positif dan signifikan terhadap nilai perusahaaan.

Pertumbuhan perusahaan dinyatakan dengan perubahan (penurunan atau peningkatan) total aset saat ini dibandingkan dengan perubahan total aset masa lalu. Pertumbuhan perusahaan sangat diharapkan oleh pihak internal maupun pihak eksternal, karena pertumbuhan perusahaan yang baik dapat memberikan sinyal positif terhadap perkembangan perusahaan. Perusahaan yang memiliki pertumbuhan total aktiva yang besar akan lebih mudah untuk mendapatkan perhatian dari pihak investor maupun kreditor karena mencerminkan perusahaan tersebut mampu menghasilkan laba yang dimanfaatkan untuk penambahan jumlah aktiva yang kemudian dapat meningkatkan nilai perusahaan.

Signaling theory menyatakan bahwa Informasi mengenai jenis pengeluaran investasi memiliki pengaruh besar terhadap nilai perusahaan, karena dapat memberikan sinyal tentang pertumbuhan pendapatan yang diharapkan di masa depan, yang selanjutnya akan meningkatkan harga saham sebagai indikator nilai peusahaan. Hal ini sejalan dengan penelitian yang dilakukan oleh Li et al. (2012) dan Maryam (2014) yang menunjukkan bahwa pertumbuhan perusahaan berpengaruh positif dan signifikan terhadap nilai perusahaan dan perubahan harga saham, yang artinya bahwa informasi tentang adanya pertumbuhan perusahaan direspon positif oleh investor, sehingga meningkatkan harga saham. Berdasarkan uraian di atas, dirumuskan hipotesis sebagai berikut: 
$\mathrm{H}_{4}$ : Pertumbuhan aset berpengaruh positif dan signifikan terhadap nilai perusahaan

Silaban (2016) menyatakan bahwa laba bersih perusahaan dapat dibagikan kepada pemegang saham sebagai dividen atau laba ditahan untuk membiayai investasi perusahaan. Dividen memiliki informasi sebagai syarat prospek perusahaan. Perusahaan yang berkualitas baik dengan sengaja akan memberikan sinyal pada pasar, dengan demikian pasar diharapkan dapat membedakan perusahaan yang berkualitas baik dan buruk. Besarnya dividen yang akan dibagikan kepada para pemegang saham menjadi daya tarik bagi investor karena menurut bird in the hand theory investor cenderung lebih menyukai dividen dibandingkan dengan capital gain karena dividen dianggap bersifat lebih pasti. Banyaknya investor yang berinvestasi di perusahaan tersebut dapat menyebabkan meningkatnya harga saham sehingga dengan meningkatnya haga saham akan meningatkan nilai perusahaan itu sendiri.

Perusahaan yang dapat meningkatkan pembayaran dividen akan dipandang memiliki kinerja yang baik, sehingga kebijakan dividen memiliki pengaruh positif terhadap nilai perusahaan. Hal ini didukung oleh hasil penelitian yang dilakukan oleh Wijaya dan Wibawa (2010), Nurhayati (2013) dan Devianasari (2015) yang menunjukkan adanya pengaruh positif dan signifikan antara kebijakan dividen terhadap nilai perusahaan. Sehingga dari pernyataan tersebut dapat dirumuskan hipotesis sebagai berikut:

$\mathrm{H}_{5}$ : Kebijakan dividen berpengaruh positif dan signifikan terhadap nilai perusahaan 
Pembayaran dividen yang optimal dapat dilihat sebagai tanda dari profitabilitas di masa yang akan datang. Perusahaan yang dapat menjaga atau bahkan meningkatkan laba dapat dilihat sebagai sinyal positif oleh investor yang berhubungan dengan kinerja perusahaan, jadi respon positif dari investor akan meningkatkan nilai perusahaan dikarenakan tujuan utama investor menanamkan modalnya di perusahaan terbuka adalah untuk mendapatkan dividen (Wijaya dan Sedana, 2015). Sehingga dari pernyataan tersebut dapat dirumuskan hipotesis sebagai berikut:

$\mathrm{H}_{6}$ : Profitabilitas berpengaruh positif dan signifikan terhadap nilai perusahaan melaui kebijakan dividen

Pertumbuhan aset yang meningkat akan memiliki prospek yang menguntungkan dalam investasi karena kemungkinan return yang akan diperoleh juga tinggi sehingga menjadi sinyal positif bagi investor yang menyebabkan meningkatnya harga saham (Ratnawati, 2007). Pertumbuhan aset mempunyai efek yang kuat terhadap nilai perusahaan terutama dalam perusahaan kecil dan menengah, karena dengan melihat investasi perusahaan atau kegiatan pembiayaan yang dilakukan, maka investor dapat memprediksi tingkat return yang akan didapatkan (Rismawati dan Dana, 2015). Sehingga dari pernyataan tersebut dapat dirumuskan hipotesis sebagai berikut:

$\mathrm{H}_{7}$ : Pertumbuhan aset berpengaruh positif dan signifikan terhadap nilai perusahaan melalui kebijakan dividen 


\section{METODE PENELITIAN}

Profitabilitas $\left(\mathrm{X}_{1}\right)$ diukur dengan Return On Equity (ROE) yaitu perbandingan aktiva laba bersih dengan ekuitas perusahaan (Kasmir, 2014:135) pada masing - masing perusahaan manufaktur yang terdaftar pada Bursa Efek Indonesia yang dinyatakan dalam persentase $(\%)$

$$
R O E=\frac{\text { Laba Berrih }}{\text { Modal Sendiri }} \times 100 \% \ldots
$$

Pertumbuhan Aset $\left(\mathrm{X}_{2}\right)$ diukur dengan rasio pertumbuhan aktiva. Pertumbuhan dihitung dengan perbandingan selisih aktiva pada waktu t dengan t1 dibagi aktiva t-1 (Chen dan Chen, 2011). Pertumbuhan dihitung dari masingmasing perusahaan manufaktur di Bursa Efek Indonesia yang dinyatakan dalam persentase $(\%)$.

$$
\text { Pertumbuhan aset }=\frac{\mathrm{TAt}_{-\mathrm{TA}} \mathrm{T}-1}{\mathrm{TA}_{\mathrm{t}-1}} \times 100 \%
$$

Kebijakan Dividen ( $\mathrm{Y}_{1}$ ) diukur dengan Dividend Payout Ratio (DPR) yaitu perbandingan dividen per lembar saham dengan laba per lembar saham pada masing - masing perusahaan manufaktur yang terdaftar pada Bursa Efek Indonesia yang dinyatakan dalam persentase $(\%)$.

$\mathrm{DPR}=\frac{\text { Dividen per lembar }}{\text { Laba per lembar aham }}$

Nilai Perusahaan $\left(\mathrm{Y}_{2}\right)$ diukur dengan perbandingan harga per lembar saham dengan nilai buku saham pada masing - masing perusahaan manufaktur yang terdaftar pada Bursa Efek Indonesia.

$$
P B V=\frac{\text { Harga perlembar saham }}{\text { Nilai buku saham }}
$$


Data kualitatif penelitian ini adalah daftar nama perusahaan Manufaktur di Bursa Efek Indonesia serta gambaran umum masing-masing perusahaan yang menjadi sampel penelitian. Data kuantitatif yang digunakan dalam penelitian ini berupa laporan keuangan perusahaan Manufaktur di Bursa Efek Indonesia pada tahun 2013 - 2016 yang dipublikasikan melalui www.idx.com.

Penelitian ini menggunakan data sekunder dimana data yang digunakan berasal dari pihak lain yang sebelumnya telah mengumpulkan dan mengolah data tersebut, yang dalam penelitian ini pihak lain yang dimaksud adalah melalui website Bursa Efek Indonesia www.idx.com.

Populasi penelitian ini adalah perusahaan Manufaktur yang terdaftar di Bursa Efek Indonesia selama periode 2013 - 2016 yang berjumlah 144 perusahaan. Sampel ditentukan dengan metode purposive sampling yaitu menentukan kriteria tertentu dalam menentukan sampel yang akan digunakan. Kriteria yang digunakan dalam penelitian ini adalah perusahaan yang memberikan dividen secara berturut - turut pada tahun 2013 - 2016.

Penelitian ini menggunakan metode penelitian observasi non participant atau metode pengumpulan data dengan pengamatan, dimana peneliti tidak terlibat langsung dalam aktivitas tetapi hanya sebagai pengamat independen. Kumpulan laporan keuangan perusahaan diperoleh melalui website Bursa Efek Indonesia www.idx.com. Periode penelitian meliputi tahun 2013-2016.

Teknik analisis yang digunakan dalam penelitian ini adalah analisis jalur (path analaysis). Analisis jalur digunakan untuk mengetahui dan memperoleh 
gambaran mengenai pengaruh profitabilitas dan pertumbuhan aset terhadap kebijakan dividen dan nilai perusahaan pada perusahaan manufaktur di bursa efek indonesia. Menurut Riduwan dan Kuncoro (2011:2), model path analysis digunakan untuk menganalisis pola hubungan antar variabel dengan tujuan untuk mengetahui pengaruh langsung maupun tidak langsung seperangkat variabel bebas (independent) terhadap variabel terikat (dependent). Gudono (2012:232) menyatakan bahwa path analysis merupakan perluasan dari analisis regresi, maka dari itu segala asumsi dalam analisis regresi juga berlaku dalam path analysis.

\section{HASIL DAN PEMBAHASAN}

Untuk memperjelas dan mempermudah pemahaman atas hasil penelitian ini, akan dideskripsikan hasil dari masing-masing faktor yang menjadi variabel dalam penelitian ini. Hasil statistic deskriptif disajikan pada tabel 2 berikut ini.

Tabel 2.

\section{Statistik Deskriptif Variabel}

\begin{tabular}{lcrrrr}
\hline & N & Minimum & Maximum & \multicolumn{1}{c}{ Mean } & \multicolumn{1}{c}{ Std. Deviation } \\
\hline ROE & 80 & -4.00 & 76.00 & 15.6375 & 13.15943 \\
GROWTH & 80 & -37.00 & 75.00 & 4.6375 & 18.98717 \\
DPR & 80 & -60.46 & 137.71 & 43.6406 & 32.02220 \\
PBV & 80 & 9.44 & 2229.15 & 318.1912 & 381.26421 \\
Valid N (listwise) & 80 & & & & \\
\hline Sumber : data sekunder diolah, 2017 & & & &
\end{tabular}

Pada tabel 2 dapat dilihat hasil uji deskriptif masing-masing variabel. Nilai minimum return on equity sebesar -4.00 dimiliki oleh PT. Indomobil Sukses Internasional Tbk. dan nilai maksimum sebesar 76.00 dimiliki oleh PT. HM Sampoerna Tbk. Nilai minimum growth sebesar -37.00 dimiliki oleh PT. Indomobil Sukses Internasional Tbk dan nilai maksimum sebesar 75.00 dimiliki oleh PT. Selamat Sempurna Tbk. Nilai minimum untuk dividend payout ratio sebesar -60.46 yang dimiliki oleh PT. Indomobil Sukses Internasional Tbk dan 
nilai maksimum sebesar 137.71 dimiliki oleh PT. HM Sampoerna Tbk. Nilai minimum price to book value sebesar 9.44 dimiliki oleh PT Pabrik Bekas Tjiwi kimia, dan nilai maksimum sebesar 2229.15 dimiliki oleh PT. HM Sampoerna Tbk.

Bentuk diagram jalur dibawah ini menggambarkan secara singkat tentang hubungan antara setiap variabel yaitu profitabilitas (X1), pertumbuhan aset (X2) sebagai variabel independent dan kebijakan dividen (Y1), nilai perusahaan (Y2) sebagai variabel dependent.

Signaling theory menyatakan bahwa profitabilitas dan pengeluaran investasi memberikan sinyal positif mengenai pertumbuhan perusahaan di masa yang akan datang. Informasi mengenai jenis pengeluaran investasi memiliki pengaruh besar terhadap nilai perusahaan, karena dapat memberikan sinyal tentang pertumbuhan pendapatan yang diharapkan di masa depan, yang selanjutnya akan meningkatkan harga saham sebagai indikator nilai peusahaan. Keuntungan yang diperoleh perusahaan dan kinerja perusahaan ditentukan salah satunya dengan keputusan investasi yang dilakukan. Keputusan ini sangat penting karena jika salah dalam mengambil keputusan, maka akan mengganggu kelangsungan hidup peusahaan. Manajer dalam hal ini harus memiliki kinerja yang baik sehingga dapat menjaga perkembangan investasi dengan demikian dapat mencapai tujuan perusahaan melalui kesejahteraan pemegang saham dan peningkatan nilai perusahaan ( Noerirawan dan Abdul, 2012). 


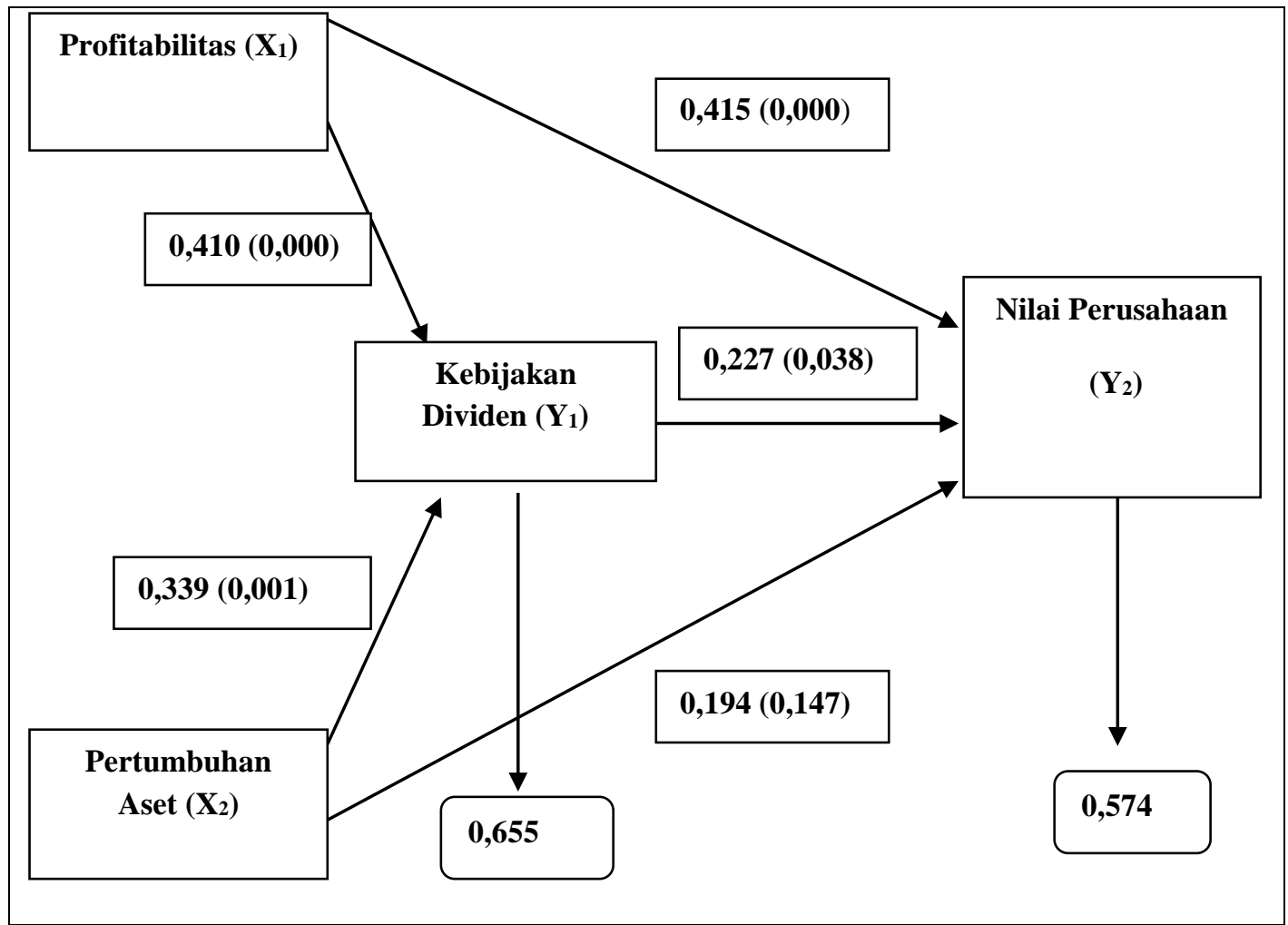

Gambar 2. Diagram Jalur Pengaruh Profitabilitas (ROE), Pertumbuhan Aset, Kebijakan Dividen (DPR) terhadap Nilai Perusahaan (PBV)

Sumber : data sekunder diolah, 2017

Bentuk diagram jalur diatas menjelaskan hubungan antara profitabilitas (X1) terhadap nilai perusahaan (Y2) memiliki standar koefisien 0,415 dengan nilai signifikan 0,000. Pengaruh Pertumbuhan Aset (X2) terhadap nilai perusahaan (Y2) memiliki standar koefisien 0,194 dan signifikansi 0,147. Selanjutnya pengaruh kebijakan dividen (Y1) terhadap nilai perusahaan (Y2) memiliki standar koefisien 0,227 dan signifikansi 0,038. Hubungan langsung antara profitabilitas (X1) terhadap kebijakan dividen (Y1) memiliki standar koefisien 0,410 dan signifikansi 0,000. Variabel selanjutnya yaitu pertumbuhan aset (X2) terhadap kebijakan dividen (Y1) memiliki standar koefisien 0,339 dan 
signifikansi 0,001. Terakhir adalah nilai dari persamaan struktural dari kebijakan dividen (Y1) yaitu 0,655 dan nilai perusahaan (Y2) 0,574.

Tabel 3.

Koefisien Regresi Substruktur 1

\begin{tabular}{|c|c|c|c|c|c|c|}
\hline & Model & $\begin{array}{l}\text { Sum of } \\
\text { Squares }\end{array}$ & $d f$ & Mean Square & $\boldsymbol{F}$ & Sig. \\
\hline \multirow{3}{*}{1} & Regression & 27963.820 & 2 & 13981.910 & 20.296 & $.000^{\mathrm{b}}$ \\
\hline & Residual & 53044.460 & 77 & 688.889 & & \\
\hline & Total & 81008.280 & 79 & & & \\
\hline \multicolumn{7}{|c|}{ a. Dependent Variable: DPR } \\
\hline
\end{tabular}

Hasil uji F yang diperoleh menunjukkan nilai F sebesar 20,296 dengan signifikansi $0,000<0,05$ (tingkat signifikansi yang digunakan). Hal ini menunjukkan bahwa ROE dan GROWTH berpengaruh secara simultan dan signifikan terhadap DPR.

Berdasarkan Tabel 4 diketahui bahwa nilai signifikansi sebesar 0,000 $<0,05$ maka $\mathrm{H}_{0}$ diterima, hasil ini menunjukkan adanya pengaruh yang signifikan antara ROE terhadap DPR pada Perusahaan Manufaktur yang terdaftar di BEI. Nilai beta 0,999 menunjukkan arah yang positif. Nilai ini memiliki arti bahwa ROE berpengaruh positif terhadap DPR. Jika ROE pada Perusahaan Manufaktur yang terdaftar di BEI meningkat, maka DPR akan meningkat pula, begitu juga sebaliknya.

Tabel 4.

Koefisien Regresi Substruktur 1

\begin{tabular}{|c|c|c|c|c|c|c|}
\hline & \multirow[t]{2}{*}{ Model } & \multicolumn{2}{|c|}{$\begin{array}{c}\text { Unstandardized } \\
\text { Coefficients }\end{array}$} & \multirow{2}{*}{$\begin{array}{c}\text { Standardized } \\
\text { Coefficients } \\
\text { Beta }\end{array}$} & \multirow[t]{2}{*}{$T$} & \multirow[t]{2}{*}{ Sig. } \\
\hline & & B & Std. Error & & & \\
\hline \multirow{3}{*}{1} & (Constant) & 25.370 & 4.575 & & 5.546 & .000 \\
\hline & ROE & .999 & .230 & .410 & 4.340 & .000 \\
\hline & GROWTH & .572 & .160 & .339 & 3.585 & .001 \\
\hline \multicolumn{7}{|c|}{ a. Dependent Variable: DPR } \\
\hline
\end{tabular}

Sumber : data sekunder diolah, 2017 
Berdasarkan Tabel 4 diketahui bahwa nilai signifikansi GROWTH sebesar $0,01<0,05$, maka $\mathrm{H}_{0}$ diterima. Hasil ini menunjukkan adanya pengaruh yang signifikan antara GROWTH terhadap DPR pada Perusahaan Manufaktur yang terdaftar di BEI. Nilai beta 0,572 menunjukkan arah yang positif. Nilai ini memiliki arti bahwa GROWTH berpengaruh positif terhadap DPR. Jika GROWTH mengalami peningkatan, maka DPR pada Perusahaan Manufaktur yang terdaftar di BEI juga meningkat.

Tabel 5.

Koefisien Regresi Substruktur 2

\begin{tabular}{lllllll}
\hline \multicolumn{1}{c}{ Model } & Sum of Squares & \multicolumn{1}{c}{$\boldsymbol{d f}$} & Mean Square & \multicolumn{1}{c}{ F } & Sig. \\
\hline Regression & 4896753.996 & 3 & 1632251.332 & 18.833 & $.000^{\mathrm{b}}$ \\
1 Residual & 6586875.710 & 76 & 86669.417 & & \\
$\quad$ Total & 11483629.707 & 79 & & & \\
a. Dependent Variable: PBV & & & & \\
b. Predictors: (Constant), DPR, GROWTH, ROE & & \\
Sumber : data sekunder diolah, 2017
\end{tabular}

Hasil uji $\mathrm{F}$ yang diperoleh menunjukkan nilai $\mathrm{F}$ sebesar 18,833 dengan signifikansi $0,000<0,05$ (tingkat signifikansi yang digunakan). Hal ini menunjukkan bahwa ROE, GROWTH dan DPR berpengaruh secara simultan dan signifikan terhadap PBV.

Tabel 6.

Koefisien Regresi Substruktur 2

\begin{tabular}{|c|c|c|c|c|c|c|}
\hline & \multirow[t]{2}{*}{ Model } & \multicolumn{2}{|c|}{$\begin{array}{c}\text { Unstandardized } \\
\text { Coefficients }\end{array}$} & \multirow{2}{*}{$\begin{array}{c}\text { Standardized } \\
\text { Coefficients } \\
\text { Beta }\end{array}$} & \multirow[t]{2}{*}{$T$} & \multirow[t]{2}{*}{ Sig. } \\
\hline & & $\boldsymbol{B}$ & Std. Error & & & \\
\hline \multirow{4}{*}{1} & (Constant) & -5.683 & 60.701 & & -.094 & .926 \\
\hline & ROE & 12.021 & 2.880 & .415 & 4.174 & .000 \\
\hline & GROWTH & 3.903 & 1.933 & .194 & 2.020 & .047 \\
\hline & DPR & 2.699 & 1.278 & .227 & 2.112 & .038 \\
\hline
\end{tabular}

Sumber : data sekunder diolah, 2017

Berdasarkan Tabel 7 diketahui bahwa nilai signifikansi sebesar 0,000 $<0,05$ maka $\mathrm{H}_{0}$ diterima, hasil ini menunjukkan adanya pengaruh yang signifikan antara 
ROE terhadap PBV pada Perusahaan Manufaktur yang terdaftar di BEI. Nilai beta 12,021 menunjukkan arah yang positif, nilai ini memiliki arti bahwa ROE berpengaruh positif terhadap PBV. Jika ROE pada Perusahaan Manufaktur yang terdaftar di BEI meningkat, maka PBV akan meningkat pula, dan begitu juga sebaliknya.

Berdasarkan Tabel 7 diketahui bahwa nilai signifikansi sebesar 0,047 $<0,05$ maka $\mathrm{H}_{0}$ diterima. Hasil ini menunjukkan adanya pengaruh yang signifikan antara GROWTH terhadap PBV pada Perusahaan Manufaktur yang terdaftar di BEI. Nilai beta 3,903 menunjukkan arah yang positif, nilai ini memiliki arti bahwa GROWTH berpengaruh positif terhadap PBV. Jika GROWTH pada Perusahaan Manufaktur yang terdaftar di BEI mengalami peningkatan, maka PBV juga akan semakin tinggi.

Berdasarkan Tabel 7 diketahui bahwa nilai signifikansi sebesar 0,038 $<0,05$ maka $\mathrm{H}_{0}$ diterima. Hasil ini menunjukkan adanya pengaruh yang signifikan antara DPR terhadap PBV pada Perusahaan Manufaktur yang terdaftar di BEI. Nilai beta 2,699 menunjukkan arah yang positif, nilai ini memiliki arti bahwa DPR berpengaruh positif terhadap PBV. Jika DPR pada Perusahaan Manufaktur yang terdaftar di BEI meningkat, maka PBV juga akan meningkat.

Berdasarkan hasil analisis jalur (path), maka dapat dihitung pengaruh langsung, pengaruh tidak langsung dan pengaruh total dari model yang telah dibuat. Perhitungan pengaruh langsung, tidak langsung dan total tersebut dapat dilihat pada tabel berikut: 
Tabel 7.

Pengaruh Langsung, Pengaruh Tidak Langsung dan Pengaruh Total

\begin{tabular}{lll}
\hline Variabel & \multicolumn{1}{c}{ Koefisien } & Signifikansi \\
\hline Pengaruh Langsung: & & \\
ROE $\rightarrow$ PBV & 0,415 & 0,000 \\
GROWTH $\rightarrow$ PBV & 0,194 & 0,147 \\
DPR $\rightarrow$ PBV & 0,227 & 0,038 \\
ROE $\rightarrow$ DPR & 0,410 & 0,000 \\
GROWTH $\rightarrow$ DPR & 0,339 & 0,001 \\
Pengaruh Tidak Langsung: & & \\
ROE $\rightarrow$ DPR $\rightarrow$ PBV & $(0,410) \times(0,227)=0,093$ \\
GROWTH $\rightarrow$ DPR $\rightarrow$ PBV & $(0,339) \times(0,227)=-0,007$ \\
Pengaruh Total: & & \\
ROE $\rightarrow$ PBV & $(0,415)+(0,093)=0,508$ & \\
(ROE $\rightarrow$ DPR $\rightarrow$ PBV) & & \\
GROWTH $\rightarrow$ PBV & & \\
$($ GROWTH $\rightarrow$ DPR $\rightarrow$ PBV) & $(0,194)+(0,007)=-0,201$ & \\
Sumber $:$ data sekunder diolah, 2017 &
\end{tabular}

Besarnya pengaruh variabel profitabilitas terhadap nilai perusahaan adalah 0,415, sedangkan pengaruh tidak langsung melalui kebijakan dividen adalah 0,093. Sehingga total pengaruh variabel profitabilitas terhadap nilai perusahaan adalah 0,508 .

Besarnya pengaruh variabel pertumbuhan aset terhadap nilai perusahaan adalah 0,194 , sedangkan pengaruh tidak langsung melalui kebijakan dividen adalah 0,007. Sehingga total pengaruh variabel pertumbuhan aset adalah 0,201.

$$
\begin{aligned}
\mathrm{R}^{2} \mathrm{~m} & =1-\left(\mathrm{e}_{1}\right)^{2}\left(\mathrm{e}_{2}\right)^{2} \\
& =1-(0,655)^{2}(0,574)^{2} \\
& =1-(0,429)(0,329) \\
& =1-0,141=0,859
\end{aligned}
$$

Variasi data yang dipengaruhi oleh model sebesar 85,9\% artinya informasi yang terkandung dalam data sebesar $85,9 \%$ dapat dijelaskan oleh model, sedangkan sisanya sebesar 14,1\% dijelaskan oleh variabel lain diluar model. 


\section{Pengaruh Profitabilitas Terhadap Kebijakan Dividen}

Hasil penelitian ini menunjukkan bahwa Profitabilitas berpengaruh positif dan signifikan terhadap Kebijakan Dividen pada Perusahaan Manufaktur yang Terdaftar di BEI Periode 2013-2016. Hasil penelitian ini mendukung hipotesis pertama yaitu Profitabilitas berpengaruh positif dan signifikan terhadap Kebijakan Dividen. Arah positif tersebut memiliki arti bahwa semakin tinggi Profitabilitas yang dimiliki maka Kebijakan Dividen pada suatu perusahaan akan meningkat, begitu juga sebaliknya. Hasil penelitian ini sejalan dengan hasil penelitian yang dilakukan oleh (Silaban, 2016) dan (Wijaya dan Sedana, 2015).

\section{Pengaruh Pertumbuhan Aset Terhadap Kebijakan Dividen}

Hasil penelitian ini menunjukkan bahwa pertumbuhan aset berpengaruh positif dan signifikan terhadap Kebijakan Dividen pada Perusahaan Manufaktur yang Terdaftar di BEI Periode 2013-2016. Hasil penelitian ini mendukung hipotesis kedua yaitu pertumbuhan aset berpengaruh positif dan signifikan terhadap Kebijakan Dividen. Arah positif tersebut memiliki arti bahwa semakin tinggi pertumbuhan aset yang dimiliki maka kebijakan dividen pada suatu perusahaan akan meningkat, begitu juga sebaliknya. Hasil penelitian ini sejalan dengan hasil penelitian yang dilakukan oleh Setiawan dan Phua (2013), Corina (2012) , Masdupi (2012) dan Ismail (2016).

\section{Pengaruh Profitabilitas Terhadap Nilai Perusahaan}

Hasil penelitian ini menunjukkan bahwa profitabilitas berpengaruh positif dan signifikan terhadap nilai perusahaan pada Perusahaan Manufaktur yang Terdaftar di BEI Periode 2013-2016. Hasil penelitian ini mendukung hipotesis 
ketiga yaitu profitabilitas berpengaruh positif dan signifikan terhadap nilai perusahaan. Arah positif tersebut memiliki arti bahwa semakin tinggi profitabilitas yang dimiliki maka nilai pada suatu perusahaan akan meningkat, begitu juga sebaliknya. Hasil penelitian ini sejalan dengan hasil penelitian yang dilakukan oleh Rizqia dkk. (2013) dan Wijaya dan Sedana (2015)

\section{Pengaruh Pertumbuhan Aset Terhadap Nilai Perusahaan}

Hasil penelitian ini menunjukkan bahwa pertumbuhan aset berpengaruh positif dan signifikan terhadap nilai perusahaan pada Perusahaan Manufaktur yang Terdaftar di BEI Periode 2013-2016. Hasil penelitian ini mendukung hipotesis keempat yaitu pertumbuhan aset berpengaruh positif dan signifikan terhadap nilai perusahaan. Arah positif tersebut memiliki arti bahwa semakin tinggi pertumbuhan aset yang dimiliki maka nilai pada suatu perusahaan akan meningkat, begitu juga sebaliknya. Hasil penelitian ini sejalan dengan hasil penelitian yang dilakukan oleh Li et al. (2012) dan Maryam (2014).

Berdasarkan Signaling theory, informasi mengenai jenis pengeluaran investasi memiliki pengaruh besar terhadap nilai perusahaan, karena dapat memberikan sinyal tentang pertumbuhan pendapatan yang diharapkan di masa depan, yang selanjutnya akan meningkatkan harga saham sebagai indikator nilai peusahaan.

\section{Pengaruh Kebijakan Dividen Terhadap Nilai Perusahaan}

Hasil penelitian ini menunjukkan bahwa kebijakan dividen berpengaruh positif dan signifikan terhadap nilai perusahaan pada Perusahaan Manufaktur yang Terdaftar di BEI Periode 2013-2016. Hasil penelitian ini mendukung 
hipotesis kelima yaitu kebijakan dividen berpengaruh positif dan signifikan terhadap nilai perusahaan. Arah positif tersebut memiliki arti bahwa semakin besar dividen yang dibayarkan maka nilai pada suatu perusahaan akan meningkat, begitu juga sebaliknya. Hasil penelitian ini sejalan dengan hasil penelitian yang dilakukan oleh Wijaya dan Wibawa (2010), Nurhayati (2013) dan Devianasari (2015)

\section{Pengaruh Profitabilitas terhadap nilai perusahaan melalui kebijakan dividen}

Hasil penelitian ini menunjukan bahwa profitabilitas berpengaruh positif terhadap nilai perusahaan melalui kebijakan dividen pada perusahaan manufaktur yang terdaftar di BEI tahun 2013-2016. Hasil penelitian ini sesuai dengan hipotesis keenam. Semakin tinggi profitabilitas maka semakin besar juga dividen yang dibagikan kepada pemegang saham sehingga mampu meningkatkan nilai perusahaan karena makmurnya pemegang saham.

\section{Pengaruh pertumbuhan aset terhadap nilai perusahaan melalui kebijakan dividen}

Hasil penelitian ini menunjukan bahwa pertumbuhan aset berpengaruh positif terhadap nilai perusahaan melalui kebijakan dividen pada perusahaan manufaktur yang terdaftar di BEI tahun 2013-2016. Hasil penelitian ini sesuai dengan hipotesis ketujuh. Semakin tinggi pertumbuhan aset maka semakin besar juga dividen yang dibagikan kepada pemegang saham sehingga mampu meningkatkan nilai perusahaan karena makmurnya pemegang saham dan meningkatkan harga saham. 
Hasil penelitian ini memiliki implikasi secara teoritis dan praktis yaitu, penelitian ini menyatakan bahwa profitabilitas dan pertumbuhan aset berpengaruh positif terhadap kebijakan dividen dan nilai perusahaan baik secara langsung maupun tidak langsung sehingga mampu memberikan informasi dan pengetahuan dalam memperkuat teori nilai perusahaan dan dapat digunakan sebagai dasar penelitian penelitian selanjutnya dalam hal teori maupun konsep yang berkaitan dengan penelitian ini. Secara praktis hasil dari penelitian ini dapat memberikan informasi kepada manajer-manajer perusahaan dalam membuat keputusan untuk memaksimalkan nilai perusahaan dengan memperhatikan profitabilitas, pertumbuhan aset dan kebijakan dividen karena dengan profitabilitas, pertumbuhan aset yang tinggi dan pembayaran dividen yang lancer akan meningkatkan nilai peusahaan.

\section{SIMPULAN}

Berdasarkan pembahasan yang telah diuraikan sebelumnya, maka diperoleh simpulan sebagai berikut. Profitabilitas berpengaruh positif signifikan terhadap kebijakan dividen Perusahaan Manufaktur yang tedaftar di BEI periode 20132016, yang ditunjukan oleh nilai koefisien $(0,410)$ dan signifikansi $(0,000)$. Pertumbuhan aset berpengaruh positif dan signifikan terhadap kebijakan dividen pada Perusahaan Manufaktur yang tedaftar di BEI periode 2013-2016, yang ditunjukan oleh nilai koefisien $(0,339)$ dan signifikansi $(0,001)$.

Profitabilitas berpengaruh positif dan signifikan terhadap nilai perusahaan pada Perusahaan Manufaktur yang tedaftar di BEI periode 2013-2016, yang ditunjukan dengan nilai koefisien $(0,415)$ dan signifikansi $(0,000)$. Pertumbuhan 
aset berpengaruh positif dan signifikan terhadap nilai perusahaan pada Perusahaan Manufaktur yang tedaftar di BEI periode 2013-2016, yang ditunjukan dengan nilai koefisien $(0,194)$ dan signifikansi $(0,147)$. Kebijakan dividen berpengaruh positif dan signifikan terhadap nilai perusahaan pada Perusahaan Manufaktur yang tedaftar di BEI periode 2013-2016, yang ditunjukan dengan nilai koefisien $(0,227)$ dan signifikansi $(0,038)$.

Profitabilitas berpengaruh positif terhadap nilai perusahaan melalui kebijakan dividen pada perusahaan manufaktur yang terdaftar di BEI periode 2013-2016, ditunjukan dengan nilai pengaruh total sebesar 0,508. Pertumbuhan aset berpengaruh positif terhadap nilai perusahaan melalui kebijakan dividen pada perusahaan manufaktur yang terdaftar di BEI periode 2013-2016, ditunjukan dengan nilai pengaruh total sebesar 0,201 .

Bagi perusahaan emiten diharapkan lebih teliti dan cermat dalam menentukan menahan laba dan membagikan laba kepada pemegang saham karena akan mempengaruhi tinggi rendahnya nilai perusahaan dan calon investor lebih teliti dalam berinvestasi dengan memperhatikan nilai perusahaan. Bagi peneliti selanjutnya yang tertarik menganalisis mengenai nilai perusahaan dapat menggunakan indikator keuangan lainnya seperti price earning ratio (PER) dan Market Book Ratio (MBR) sehingga dapat memperoleh hasil penelitian yang lebih maksimal.

\section{REFERENSI}

Aqel, Saher,. 2016. An Empirical Investigation of Corporate Dividend Payout Policy in an Emerging Market: Evidence from Palestine Securities Exchange. Research Journal of Finance and Accounting, 7(6): 7-16. 
Brigham, Eugene F. dan Joel F. Houston. 2011. Essentials of Financial Management. Jakarta: Salemba Empat.

Chen, Shun-Yu., dan Liu-Ju Chen. 2011. Capital Structure Determinants : An Empirical Study in Taiwan. African Journal of Business Management 5 (27): 10974-10983.

Cooper, Michael J. Huseyin Gulen and Michael J. 2008. Asset Growth and the Cross-Section of Stock Returns. The Journal of Finance, 13(4): 1609- 1651.

Corina, Ioamas. 2012. Factors That Affect Dividend Policies. Romanian Economic and Business Review 4(2): 83-88.

Deitiana, Tita. 2009. Faktor-Faktor yang Mempengaruhi Kebijakan Pembayaran Dividen Kas,Jurnal Bisnis dan Akuntansi, 1(1): 38-63.

Devianasari, Ni Luh dan Ni Putu Santi Suryantini. 2015. Pengaruh Price Earning Ratio, Debt To Equity Ratio, Dan Dividen Payout Ratio Terhadap Nilai Perusahaan Pada Perusahaan Manufaktur Yang Terdaftar Di Bursa Efek Indonesia. E-Jurnal Manajemen Unud, 4(11): 3646 - 3674.

Gudono. 2012. Analisis Data Multivariate. Edisi Kedua. Yogyakarta : BPFE

Ismail, Yusniliyana Yusof Suhaiza 2016. Determinants of Dividend Policy of Public Listed Companies In Malaysia. International Business and Strategy, 26(1): 1-20.

Jenni L, Bettman, Kosev Mitch and Sault Stephen J. 2011. Exploring the asset growth effect in the Australian equity market: Australian Journal of Management, 36(2): 200-216.

Kasmir. 2011. Analisis Laporan Keuangan. Cetakan Ketiga. Jakarta: PT. Raja Grafindo Persada.

Li, Xi, Ying Becker and Didier Rosenfeld, CFA. 2012. Asset Growth and Future Stock Returns:International Evidence: Financial Analysts Journal, 68(3): 51-62.

Masdupi, Erni. 2012. Pengaruh Insider Ownership, Struktur Modal, Dan Pertumbuhan Perusahaan Terhadap Kebijakan Dividen Perusahaan Syariah Yang Terdaftar Di Bursa Efek Indonesia. Journal Economac, 12(1): 9 - 14.

Maryam, Sitti. 2014. Analisis Pengaruh Firm Size, Growth, Leverage, Dan Profitabilitas Terhadap Nilai Perusahaan (Studi Pada Perusahaan Manufaktur Yang Terdaftar Di Bursa Efek Indonesia). Skripsi S1 Universitas Hasanuddin, Makasar. 
Nurhayati, Mafizatun. 2013. Profitabilitas, Likuiditas, dan Ukuran Perusahaan Pengaruhnya Terhadap Kebijakan Dividend dan Nilai Perusahaan. Jurnal Keuangan dan Bisnis, 5(2): 114 - 153.

Riduwan dan Engkos Achmad Kuncoro. 2011. Cara Menggunakan dan Memakai Path Analysis (analisis jalur) edisi revisi. Cetakan Ketiga. Bandung: Alfabeta.

Rizqia, Dwita Ayu, Aisjah, Siti, dan Sumiati. 2013. Effect of Managerial Ownership, Financial Leverage, Profitability, Firm Size, and Investment Opportunity on Dividend Policy and Firm Value. Research Journal of Finance and Accounting. 4 (11): 1-13.

Salvatore, Dominick. 2011. Managerial Economics. Jakarta: Salemba Empat

Sartono, Agus. 2010. Manajemen Keuangan Teori dan Aplikasi Edisi 4. Yogyakarta: BPFE-Yogyakarta

Setiawan, Doddy dan Lian Kee Phua. 2013 Corporate Governance and Dividend Policy in Indonesia. Business Strategy Series 1(4): 137-138.

Silaban, Dame Prawira. dan Ni Ketut Purnawati. 2016. Pengaruh Profitabilitas, Struktur Kepemilikan, Pertumbuhan Perusahaan dan Efektivitas Usaha Terhadap Kebijakan Dividen Pada Perusahaan Manifaktur. E-Jurnal Manajemen Unud, 5(2): 1251-1281

Tandelilin, Eduardus. 2010. Portofolio Investasi Teori dan Aplikasi. Yogyakarta: Kanisius.

Wiagustini, Ni Luh Putu. 2013. Dasar-Dasar Manajemen Keuangan. Denpasar. Udayana University Press.

Wijaya, Bayu Irfandi dan I.B. Pandji Sedana. Pengaruh Profitabilitas Terhadap Nilai Perusahaan (Kebijakan Dividen Dan Kesempatan Investasi Sebagai Variabel Mediasi). E-Jurnal Manajemen Unud, 4(12): 4477-4500

Wijaya, L. R. P., dan Wibawa, B. A. 2010. Pengaruh Keputusan Investasi, Keputusan Pendanaan, dan Kebijakan Dividen Terhadap Nilai Perusahaan. Kumpulan Makalah, Simposium Nasional Akuntansi, 1(3):1-21. 